International Business and Global Economy 2018, no. 37, pp. 336-347

Biznes międzynarodowy w gospodarce globalnej 2018, nr 37, s. 336-347

Edited by the Institute of International Business, University of Gdańsk

ISSN 2300-6102

e-ISSN 2353-9496

DOI 10.4467/23539496IB.18.024.9397

\author{
Dominik A. Skopiec \\ Szkoła Główna Handlowa w Warszawie
}

\title{
Rola państwa w procesie internacjonalizacji waluty Chin
}

Internacjonalizacja renminbi stanowi jedno z kluczowych zjawisk charakteryzujących współczesny międzynarodowy system walutowy. Proces ten jest następstwem wzrostu roli gospodarki Chin w gospodarce światowej oraz dążenia władz Państwa Środka do zwiększenia międzynarodowej roli renminbi, co wynika z przekonania, że znaczenie tego kraju w międzynarodowych stosunkach walutowych jest nieproporcjonalnie małe $\mathrm{w}$ stosunku do pozycji $\mathrm{w}$ realnej sferze gospodarki światowej. Chiny spełniają obecnie jedynie część kryteriów internacjonalizacji waluty krajowej. Jednakże władze tego kraju podejmują aktywne działania prowadzące do zwiększenia międzynarodowej roli renminbi. Cel artykułu stanowi zbadanie przyczyn aktywnej roli państwa $\mathrm{w}$ procesie internacjonalizacji renminbi oraz poszczególnych obszarów, w których państwo wspiera umiędzynarodowienie tej waluty. Tezą artykułu jest twierdzenie, że internacjonalizacja renminbi jest przede wszystkim rezultatem działalności władz państwa (government-led internationalization), natomiast $\mathrm{w}$ znacznie mniejszej części pozostaje procesem rynkowym (market-led internationalization). Jest to zjawisko bezprecedensowe, gdyż internacjonalizacja współczesnych walut kluczowych miała przede wszystkim charakter rynkowy. Zastosowane metody badawcze obejmują analizę danych statystycznych dotyczących zmiennych makroekonomicznych charakteryzujących gospodarkę Chin oraz danych odnoszących się do skali i obszarów międzynarodowego zastosowania renminbi, a także analizę porównawczą i analizę literatury przedmiotu. Przedstawiona $\mathrm{w}$ artykule analiza dowodzi, że aktywna rola państwa w znaczącym stopniu przyczyniła się do wzrostu międzynarodowego znaczenia oraz wykorzystania waluty Chin.

Słowa kluczowe: internacjonalizacja, państwo, waluta międzynarodowa

Klasyfikacja JEL: F02, F31, F41, G15, G18

\section{The role of state in the internationalization of the Chinese currency}

The internationalization of the Chinese currency remains one of the most vital characteristics of the contemporary international monetary system. The objective of the paper is to analyse the role of state in the internationalization of the renminbi. The paper assumes that this process is to a significant extent a government-led, as opposed to the market-led internationalization characteristic for most key international currencies. It demonstrates the criteria of national currency internationalization and evaluates their fulfilment in the case of China. It also discusses the benefits of currency internationalization and their role in determining the Chinese strategy aimed at making the renminbi an international currency. The methods applied include, in particular, comparative analysis, descriptive statistics, and literature study. The article indicates that the Chinese state 
plays an important role in the internationalization of the renminbi. The strategy of renminbi internationalization includes promoting trade settlement and foreign direct investment settlement in renminbi as well as establishing offshore centres for renminbi and bilateral swap agreements with central banks of other countries.

Keywords: internationalization, state, international currency

JEL classification: F02, F31, F41, G15, G18

\section{Wprowadzenie}

Internacjonalizacja renminbi stanowi jedno z kluczowych zjawisk charakteryzujących współczesny międzynarodowy system walutowy. Proces ten jest następstwem wzrostu roli gospodarki Chin w gospodarce światowej oraz dążenia władz Państwa Środka do zwiększenia międzynarodowej roli renminbi, co wynika z przekonania, że znaczenie tego kraju w międzynarodowych stosunkach walutowych jest nieproporcjonalnie małe $\mathrm{w}$ stosunku do jego pozycji $\mathrm{w}$ realnej sferze gospodarki światowej. Chiny spełniają obecnie jedynie część kryteriów internacjonalizacji waluty krajowej. Jednakże władze tego kraju podejmują aktywne działania prowadzące do zwiększenia międzynarodowej roli renminbi. Wyrazem dynamicznego wzrostu międzynarodowego znaczenia i wykorzystania waluty Chin stało się włączenie renminbi przez Zarząd MFW do koszyka walutowego SDR od 1 października $2016 \mathrm{r}$.

Celem artykułu jest zbadanie poszczególnych obszarów, w których państwo chińskie odgrywa aktywną rolę $\mathrm{w}$ procesie internacjonalizacji renminbi. Tezą artykułu jest twierdzenie, że internacjonalizacja renminbi stanowi przede wszystkim rezultat działalności władz państwa (government-led internationalization), natomiast $\mathrm{w}$ znacznie mniejszej części pozostaje procesem rynkowym (market-led internationalization). Jest to zjawisko bezprecedensowe, gdyż proces internacjonalizacji współczesnych walut kluczowych miał przede wszystkim charakter rynkowy.

Zastosowane metody badawcze obejmują analizę danych statystycznych dotyczących zmiennych makroekonomicznych charakteryzujących gospodarkę Chin oraz danych odnoszących się do skali i obszarów międzynarodowego zastosowania renminbi, a także analizę porównawczą i analizę literatury przedmiotu.

\section{Wzrost znaczenia Chin w gospodarce światowej jako przesłanka internacjonalizacji renminbi}

W wyniku realizowanej od $1978 \mathrm{r}$. transformacji systemowej Chiny osiągały przez ostatnie cztery dekady dynamiczny wzrost gospodarczy, dzięki czemu 
stały się drugą co do wielkości gospodarką świata oraz największym światowym eksporterem. W efekcie „polityki otwartych drzwi” Chiny przekształciły się z gospodarki zamkniętej w jedną z najbardziej otwartych gospodarek świata. Efektem otwarcia gospodarki Chin i proeksportowej strategii wzrostu gospodarczego był wzrost udziału tego kraju w handlu światowym, który uległ ogromnemu przyspieszeniu po akcesji tego kraju do Światowej Organizacji Handlu w grudniu 2001 r. W rezultacie w 2009 r. Chiny stały się największym światowym eksporterem (wyprzedzając Niemcy). Państwo Środka pozostaje również drugim światowym importerem.

Wzrost roli Chin w gospodarce światowej należy uznać za przesłankę przekształcenia waluty tego kraju, renminbi, w walutę międzynarodową, czyli taką, która jest używana i utrzymywana poza granicami kraju emitenta nie tylko dla zawierania transakcji z jego rezydentami, ale zwłaszcza w celu dokonywania transakcji między nierezydentami [Kenen, 2011]. Aby waluta krajowa mogła odgrywać rolę waluty międzynarodowej, kraj będący jej emitentem musi spełnić szereg kryteriów. Odnoszą się one w szczególności do wielkości gospodarki, poziomu rozwoju rynku finansowego, polityki gospodarczej, bilansu obrotów kapitałowych i finansowych oraz systemu kursu walutowego.

Emitentami walut międzynarodowych są zazwyczaj kraje o silnej pozycji w gospodarce światowej, których PKB stanowi znaczącą część światowego PKB, a handel zagraniczny istotną część handlu światowego. Konsekwencją dużego udziału w handlu międzynarodowym jest równie duża liczba i wartość transakcji zawieranych przez dany kraj, co zwiększa szanse na umiędzynarodowienie jego waluty. Kluczowy czynnik dla internacjonalizacji waluty krajowej stanowi dobrze rozwinięty, efektywny, głęboki i płynny rynek finansowy. Rynek taki cechuje znaczna wartość transakcji, duży obrót oraz szerokie spektrum oferowanych instrumentów finansowych, a także rozwinięta infrastruktura instytucjonalna. Musi być on także otwarty dla podmiotów niebędących rezydentami. Szczególnie ważny jest dostatecznie duży rynek papierów dłużnych, zwłaszcza rządowych, gdyż decyduje to o możliwości pełnienia przez walutę krajową funkcji waluty rezerwowej [Genberg, 2009].

Warunkiem internacjonalizacji waluty krajowej jest też liberalizacja transakcji rejestrowanych na rachunku kapitałowym i finansowym, oznaczająca swobodę obrotu walutą na międzynarodowym rynku walutowym i zawierania transakcji obejmujących w szczególności inwestycje bezpośrednie i portfelowe. Inaczej mówiąc, waluta międzynarodowa musi być walutą w pełni wymienialną. Wskazuje się także, że kraj emitujący walutę międzynarodową powinien stosować system płynnego kursu walutowego, w którym wartość waluty kształtowana jest przez interakcję popytu i podaży na rynku walutowym [Prasad, Ye, 2012, s. 2]. 
Chiny spełniają obecnie jedynie część wspomnianych uprzednio kryteriów internacjonalizacji waluty krajowej. Przede wszystkim są drugą pod względem wielkości PKB gospodarką świata, która w 2016 r. tworzyła 14,8\% światowego produktu brutto w cenach bieżących; w przypadku PKB liczonego w oparciu o parytet siły nabywczej udział ten stanowił 17,8\% [The World Bank, 2017]. Ponadto w rankingu Światowej Organizacji Handlu (ranking obejmuje kraje, nie uwzględnia natomiast ugrupowań integracyjnych) Chiny są największym światowym eksporterem (13,15\% światowego eksportu towarów w 2016 r.) oraz drugim światowym importerem (9,78\% światowego importu towarów w 2016 r.) [WTO, 2017]. Państwo Środka spełnia także kryterium stabilności pieniądza krajowego ze względu na umiarkowaną wartość wskaźnika CPI, która wynosiła 2,65\% w 2012 r., 2,62\% w 2013 r., 2,0\% w 2014 r., 1,4\% w 2015 r. i $2 \%$ w 2016 r. [The World Bank, 2017]. Zewnętrzna wartość renminbi, którą stanowi kurs walutowy, pozostaje również stabilna. Zmniejszyło się przy tym niedowartościowanie chińskiej waluty, gdyż od 2010 r. ulegała ona powolnej aprecjacji wobec dolara amerykańskiego. Ponadto za gwarancję stabilności kursu walutowego renminbi uważa się ogromne rezerwy walutowe zgromadzone przez Chiny.

Pomimo wzrostu roli Chin w gospodarce światowej i handlu międzynarodowym, kraj ten w dalszym ciągu nie spełnia niektórych kryteriów internacjonalizacji waluty narodowej. Bariery umiędzynarodowienia renminbi to przede wszystkim słabo rozwinięty krajowy rynek finansowy, kontrola przepływu kapitału, system stałego kursu walutowego, brak pełnej wymienialności, brak niezależności banku centralnego oraz autorytarny system polityczny i nierespektowanie rządów prawa [Huang, Wang, Fan, 2014, s. 9-11].

\section{Przyczyny aktywnej roli państwa w procesie internacjonalizacji renminbi}

Chiny od kilku lat podejmują działania mające na celu wspieranie internacjonalizacji renminbi. Wynikają one w znacznej mierze ze świadomości rosnącej roli Państwa Środka w gospodarce światowej i związanych z tym ambicji. Wiążą się również z przekonaniem, że znaczenie Chin w międzynarodowych relacjach walutowych jest nieproporcjonalnie małe w stosunku do pozycji tego kraju w realnej sferze gospodarki światowej. Istotna pozostaje również chęć uniezależnienia się od dolara amerykańskiego w rozliczaniu handlu zagranicznego Chin, co wynika nie tylko z przyczyn ekonomicznych, lecz stanowi również instrument zwiększenia prestiżu tego kraju w gospodarce światowej.

Przyczyną aktywnej roli państwa w procesie internacjonalizacji renminbi jest także dążenie do osiągnięcia klasycznych korzyści z internacjonalizacji waluty 
krajowej. Największa korzyść kraju emitującego walutę międzynarodową wiąże się z tzw. rentą senioralną, zwaną też senioratem (seigniorage), oznaczającą przywilej banku centralnego polegający na monopolu emisji pieniądza i osiąganiu dochodu z tego tytułu. Gdy pieniądz krajowy pełni jednocześnie funkcję pieniądza międzynarodowego, seniorat osiąga znacznie większe rozmiary [Cohen, 2012, s. 16-17]. Kraj emitujący walutę międzynarodową posiada także możliwość szerokiego zadłużania się za granicą, gdyż obligacje rządowe takich państw są dużo częściej nabywane przez inwestorów niż obligacje nominowane w walutach nieposiadających tego statusu [Papaioannou, Portes, 2008, s. 37]. Czynnikiem zwiększającym ten popyt jest pełnienie przez waluty międzynarodowe funkcji walut referencyjnych, w związku z czym banki centralne państw stosujących systemy kursu stałego nabywają znaczne ilości wspomnianych obligacji, które stanowią istotny składnik utrzymywanych rezerw walutowych. Co więcej, emitowanie waluty międzynarodowej przez dany kraj obniża rentowność jego obligacji rządowych, a więc zmniejsza koszt obsługi zadłużenia. Z drugiej strony państwo takie osiąga znacznie większe korzyści ze swoich inwestycji zagranicznych (bezpośrednich i portfelowych) w porównaniu z kosztami obsługi zaciągniętego w swojej walucie długu. Sytuacja ta określana jest mianem nadzwyczajnego przywileju (exorbitant priviledge) kraju emitującego walutę międzynarodową. Innymi słowy, nadzwyczajny przywilej pozwala emitentowi waluty międzynarodowej płacić mniej za pozyskiwanie kapitału za granicą i otrzymywać więcej za kapitał dostarczany za granicę [Eichengreen, 2011, s. 4].

Przywilejem kraju emitującego walutę międzynarodową jest też możliwość zaciągania długu za granicą we własnej walucie. Dzięki temu zmiany kursu walutowego, w szczególności deprecjacja waluty krajowej, nie mają wpływu na wielkość zadłużenia zagranicznego takiego państwa, natomiast powodują straty dla jego kredytodawców. Korzyścią z pełnienia przez walutę krajową funkcji waluty międzynarodowej jest także wygoda rezydentów, zwłaszcza eksporterów, importerów, pożyczkodawców i pożyczkobiorców, którzy w rozliczeniach z zagranicą posługują się walutą krajową i dzięki temu nie ponoszą kosztów transakcyjnych związanych z wymianą walut oraz kosztów zabezpieczenia przed ryzykiem kursowym (hedging). Korzyści związane z internacjonalizacją waluty krajowej odnoszą także banki i instytucje finansowe działające w danym kraju, gdyż mają przewagę konkurencyjną wynikającą z prowadzenia operacji w walucie międzynarodowej. Mogą one dzięki temu zwiększyć skalę działalności i efektywność. Przewagę zyskują także centra finansowe zlokalizowane w kraju będącym emitentem waluty międzynarodowej [Chinn, Frankel, 2005, s. 5-6]. Internacjonalizacja waluty krajowej wiąże się także ze wzrostem prestiżu, siły politycznej i pozycji kraju w gospodarce światowej. Kraj emitujący dominującą walutę międzynarodową jest jednocześnie potęgą polityczną i gospodarczą [Subramanian, 2011, s. 55, 99-104]. 


\section{Obszary aktywności państwa w procesie internacjonalizacji renminbi}

Realizowana przez Chiny strategia internacjonalizacji renminbi obejmuje przede wszystkim pięć obszarów: zwiększanie elastyczności systemu kursu walutowego, liberalizację rozliczeń handlowych w renminbi, liberalizację przepływów kapitału (w zakresie inwestycji bezpośrednich i portfelowych), wspieranie rozwoju centrów offshore dla renminbi oraz zawieranie umów o swapach walutowych.

Szczególne znaczenie dla internacjonalizacji renminbi ma stopniowe uelastycznianie reżimu kursowego oraz dopuszczenie systematycznej aprecjacji renminbi w stosunku do dolara amerykańskiego. W lipcu 2005 r. Ludowy Bank Chin przeprowadził reformę systemu kursowego. W miejsce trwającego od $1994 \mathrm{r}$. silnego powiązania renminbi z dolarem wprowadzono system kierowanego kursu płynnego, w którym chińska waluta oficjalnie powiązana została z koszykiem walut, a poziom kursu w większym stopniu odzwierciedlać miał interakcję popytu i podaży na rynku walutowym [Goldstein, Lardy, 2008, s. 2]. Wspomniana reforma reżimu kursowego doprowadziła do systematycznej realnej aprecjacji renminbi w stosunku do dolara, która od lipca 2005 r. do kwietnia 2013 r. wyniosła 44,8\%. W tym samym czasie nastąpiła również aprecjacja renminbi mierzona za pomocą realnego efektywnego kursu walutowego, a jej wartość osiągnęła 34\% [Report..., 2013, s. 16]. Najważniejszym efektem systematycznej aprecjacji chińskiej waluty było zmniejszenie stopnia jej niedowartościowania wobec dolara amerykańskiego. Należy podkreślić, że Chiny dokonywały również stopniowego uelastycznienia systemu kursu walutowego. Polegało to na poszerzaniu pasma dopuszczalnych wahań kursu renminbi wokół parytetu. W maju 2007 r. pasmo wahań rozszerzono $\mathrm{z} \pm 0,3 \%$ do $\pm 0,5 \%$, w kwietniu 2012 r. poszerzono je do $\pm 1 \%$, natomiast w marcu 2014 r. do $\pm 2 \%$.

Drugim kluczowym obszarem aktywności państwa w procesie internacjonalizacji renminbi była stopniowa liberalizacja rozliczeń handlowych $w$ tej walucie, rozpoczęta w lipcu 2009 r., kiedy wprowadzono program pilotażowy dla rozliczeń transakcji handlu zagranicznego w renminbi (Pilot Program of Renminbi Settlement of Cross-border Trade Transactions). Przed uruchomieniem wspomnianego programu praktycznie cały handel zagraniczny Chin rozliczany był w dolarach amerykańskich. Po wprowadzeniu programu pilotażowego części chińskich przedsiębiorstw umożliwiono rozliczanie handlu w renminbi. Zasięg geograficzny tej inicjatywy ograniczał się wówczas do pięciu chińskich miast, a partnerzy zagraniczni mogli pochodzić tylko z Hongkongu, Makau i krajów członkowskich ASEAN [Renminbi Trade Settlement Pilot Scheme, 2009]. 
Wskutek rozszerzenia zasięgu geograficznego programu pilotażowego w czerwcu $2010 \mathrm{r}$. uprawnione do rozliczania handlu w renminbi były już przedsiębiorstwa z dwudziestu chińskich prowincji, natomiast ograniczenia odnoszące się do lokalizacji partnerów zagranicznych zostały zniesione. Kolejne rozszerzenie programu nastąpiło w sierpniu 2011 r., kiedy zniesiono również ograniczenia dotyczące lokalizacji podmiotów krajowych. Efektem programu pilotażowego stał się dynamiczny wzrost udziału handlu rozliczanego w walucie chińskiej w całości obrotów handlu zagranicznego tego kraju. Ekspansja rozliczeń handlowych $\mathrm{w}$ renminbi doprowadziła ponadto do wzrostu wartości depozytów w tej walucie w bankach zlokalizowanych w Hongkongu.

Trzecim obszarem, w którym państwo prowadzi aktywną politykę wspierającą internacjonalizację renminbi, jest liberalizacja przepływów kapitału, zarówno w odniesieniu do inwestycji bezpośrednich, jak i portfelowych. Pełna liberalizacja przepływów kapitału dotyczyła zagranicznych inwestycji bezpośrednich. W rezultacie nierezydenci mają swobodę dokonywania inwestycji bezpośrednich w Chinach. W dalszym ciągu jednak kontroli podlegają przepływy kapitału stanowiące inwestycje portfelowe. $W$ przypadku tego rodzaju inwestycji przeprowadzono częściową liberalizację. W 2002 r. ustanowiono program, w ramach którego tzw. kwalifikowani zagraniczni inwestorzy instytucjonalni (Qualified Foreign Institutional Investor - QFII) mogą po uzyskaniu odpowiedniego zezwolenia inwestować $w$ akcje nominowane w renminbi na giełdach w Szanghaju i Shenzhen. W 2011 r. wprowadzono rozszerzoną wersję tej inicjatywy o nazwie Renminbi Qualified Foreign Institutional Investor (RQFII). W ramach tego programu nierezydenci mają możliwość inwestowania do określonego limitu zarówno w akcje, jak i obligacje emitowane na chińskim rynku onshore. Jeśli chodzi o liberalizację przepływów kapitału w zakresie inwestycji portfelowych dokonywanych przez rezydentów chińskich, kluczowe znaczenie miał wprowadzony w 2007 r. program ustanawiający instytucję kwalifikowanego krajowego inwestora instytucjonalnego (Qualified Domestic Institutional Investor - QDII). W ramach tego programu umożliwiono podmiotom krajowym, aczkolwiek $\mathrm{w}$ ograniczonym zakresie, inwestowanie na giełdach za granicą [Gao, Yu, 2011, s. 121].

Czwartym kluczowym obszarem strategii internacjonalizacji renminbi jest wspieranie przez Chiny rozwoju centrów offshore dla waluty tego kraju. Najważniejszym centrum offshore pozostaje Hongkong, jednakże szczególnie istotny jest ich rozwój w krajach rozwiniętych. Poza Hongkongiem do wiodących ośrodków należą obecnie Singapur i Tajwan, natomiast poza Azją Londyn, Paryż, Frankfurt i Luksemburg.

Rozwój centrum offshore w Hongkongu w odniesieniu do operacji prowadzonych w renminbi ma miejsce od 2004 r., kiedy m.in. umożliwiono tamtejszym bankom przyjmowanie depozytów w renminbi. Następnie zakres tych operacji 
był systematycznie poszerzany [Jackson, Rossi, 2011]. W 2007 r. zezwolono na emitowanie tzw. obligacji dim sum, czyli obligacji nominowanych w renminbi, emitowanych poza terytorium Chin. Początkowo katalog emitentów ograniczał się do chińskich instytucji finansowych, z czasem jednak rozszerzono go o spółki chińskie, korporacje międzynarodowe i międzynarodowe instytucje finansowe [Subacchi, 2010]. Wyraz aktywnej roli państwa w internacjonalizacji renminbi stanowi również fakt, że wspieranie międzynarodowego wykorzystania renminbi i rozwój centrum offshore w Hongkongu stały się oficjalnymi celami, sformułowanymi w planie pięcioletnim na lata 2011-2015 [Jiabao, 2011, s. 37].

Piątym obszarem, $\mathrm{w}$ którym dostrzegalna jest aktywna rola państwa w procesie internacjonalizacji renminbi, są działania mające na celu dostarczenie płynności $\mathrm{w}$ tej walucie innym krajom. Ludowy Bank Chin zawiera zatem umowy o swapach walutowych (bilateral swap agreements) z innymi bankami centralnymi, zarówno z krajów wschodzących i rozwijających się, jak i z krajów rozwiniętych. $\mathrm{W}$ odróżnieniu od swapów zawieranych przednio w ramach tzw. Inicjatywy z Chiang Mai, które posiadały charakter instrumentów ostrożnościowych i miały za zadanie dostarczyć płynności w dolarach w sytuacji wystąpienia kryzysu finansowego, celem porozumien swapowych podpisywanych od grudnia $2008 \mathrm{r}$. jest wspieranie rozliczania wzajemnego handlu i inwestycji w renminbi, a także wzmocnienie dwustronnej współpracy finansowej [Ito, 2011, s. 5-6]. Uważa się również, że nieoficjalnym celem tych porozumień jest również zachęcenie banków centralnych do utrzymywania rezerw dewizowych w renminbi. Do końca 2015 r. Ludowy Bank Chin zawarł umowy o swapach walutowych zakładających dostarczenie płynności w renminbi z prawie czterdziestoma bankami centralnymi. Najwięcej tego typu porozumień podpisano z krajami wschodzącymi i rozwijającymi się. Wszystkie porozumienia swapowe zawierane są na trzy lata, jednakże ich okres obowiązywania jest przedłużany [Skopiec, 2016].

\section{Efekty strategii internacjonalizacji renminbi}

Wskutek realizowanej przez władze Chin strategii internacjonalizacji renminbi nastąpił szybki wzrost międzynarodowego wykorzystania chińskiej waluty. Odsetek handlu zagranicznego Chin rozliczany w renminbi rósł szybko od wprowadzenia programu pilotażowego, osiągając w 2015 r. poziom 29,4\% [IMF, 2016a]. Wzrost międzynarodowego wykorzystania chińskiego pieniądza nastąpił także w odniesieniu do całego handlu światowego. W październiku 2013 r. renminbi zastąpiło euro na pozycji drugiej najważniejszej waluty w rozliczaniu handlu światowego, osiągając udział 6,64\% [SWIFT, 2013; ECB, 2014, s. 32]. 
Międzynarodowe znaczenie waluty Chin rosło także w przypadku ogółu światowych płatności. Udział renminbi pozostawał tu niższy niż w przypadku handlu międzynarodowego, niemniej jednak wykazywał tendencję wzrostową i w styczniu 2016 r. wynosił 2,45\%. Na szczególną uwagę zasługuje dynamiczny wzrost wykorzystania waluty Chin na rynkach walutowych. W $2010 \mathrm{r}$. udział renminbi w średnim dziennym obrocie na światowym rynku walutowym wynosił zaledwie 09\%, w 2013 r. stanowił 2,2\%, natomiast w 2016 r. osiągnął już poziom 4,0\% [BIS, 2013; BIS, 2016].

Zauważalny jest również wzrost znaczenia waluty Chin w światowych rezerwach walutowych. Należy pamiętać, że do 30 września 2016 r. MFW nie wyodrębnial renminbi $\mathrm{w}$ bazie COFER (Currency Composition of Official Foreign Exchange Reserves) (rezerwy w tej walucie wchodzily w zakres kategorii „inne”), jednakże badanie przeprowadzone przez Fundusz wśród państw członkowskich wiosną 2015 r. dostarcza informacji na temat rezerw utrzymywanych w walucie Chin w latach 2013-2014. Ze 130 objętych badaniem krajów rezerwy w renminbi gromadziło 27 państw w 2013 r. i 38 w 2014 r. Rezerwy utrzymywane w renminbi stanowily 0,67\% światowych rezerw walutowych w 2013 r. i 1,11\% w 2014 r. [IMF, 2015b]. W 2016 r. rezerwy w renminbi stanowiły zgodnie z danymi bazy COFER $1,08 \%$ światowych sklasyfikowanych rezerw walutowych. Nie są to wielkości znaczące, pamiętać jednak należy, że światowe rezerwy cechuje olbrzymi stopień koncentracji walutowej (rezerwy w dolarach i euro stanowily aż 83,54\% światowych rezerw w 2016 r.) [COFER, 2017].

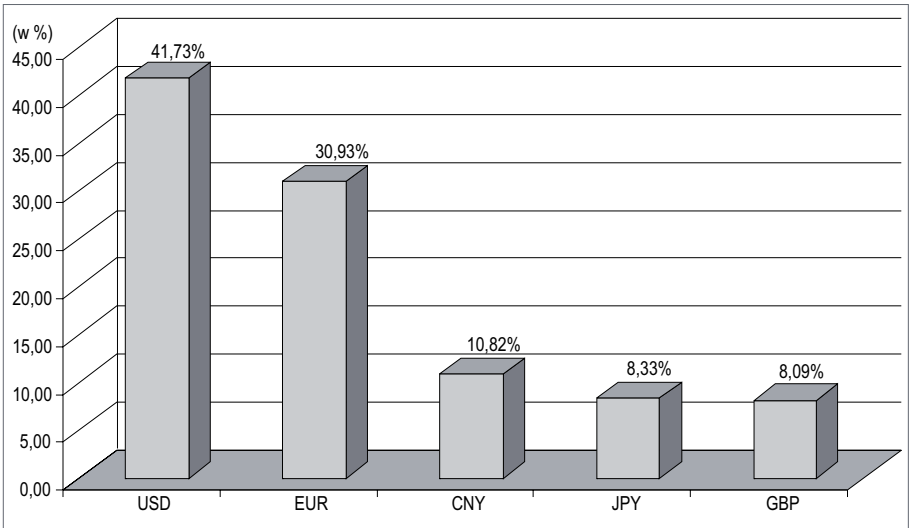

Rysunek 1. Struktura walutowa koszyka SDR od 1 października 2016 r.

Źródło: Opracowanie własne na podstawie: [IMF, 2015a].

Wyrazem dynamicznego wzrostu międzynarodowego znaczenia i wykorzystania waluty Chin stało się włączenie renminbi przez Zarząd MFW do koszyka walutowego SDR od 1 października 2016 r. Było to bezpośrednią konsekwencją 
oficjalnego nadania renminbi przez MFW statusu waluty swobodnie używanej (freely used currency). Należy podkreślić, że renminbi przyznano od początku wysoką wagę $10,82 \%$, co daje tej walucie trzecią po dolarze amerykańskim i euro pozycję w koszyku SDR. Niższe udziały mają natomiast dwie pozostałe waluty tradycyjnie wchodzące skład koszyka SDR, a mianowicie funt szterling $(8,09 \%)$ i japoński jen (8,33\%) [IMF, 2015a].

Następstwem włączenia renminbi do koszyka SDR było wyodrębnienie tej waluty w statystykach sklasyfikowanych oficjalnych rezerw walutowych, gromadzonych w bazie COFER, począwszy od 1 października 2016 r. Wskutek tego renminbi stało się ósmą walutą uwzględnianą odrębnie w statystykach rezerw walutowych MFW (obok dolara amerykańskiego, euro, jena, funta szterlinga, franka szwajcarskiego, dolara australijskiego i dolara kanadyjskiego) [IMF, 2016b].

\section{Podsumowanie}

Przedstawiona $\mathrm{w}$ artykule analiza dowodzi, że internacjonalizacja renminbi jest procesem $w$ znacznej mierze inicjowanym $i$ kierowanym przez chińskie państwo. Chiny spełniają obecnie jedynie część kryteriów internacjonalizacji waluty krajowej, jednakże władze tego kraju podejmują aktywne działania prowadzące do zwiększenia międzynarodowej roli renminbi. Wynikają one w znacznej mierze ze świadomości rosnącej roli Państwa Środka w gospodarce światowej oraz z przekonania, że znaczenie Chin w międzynarodowych relacjach walutowych jest nieproporcjonalnie małe w stosunku do pozycji tego kraju w realnej sferze gospodarki światowej. Przyczyną aktywnej roli państwa w procesie internacjonalizacji renminbi jest także dążenie do osiągnięcia klasycznych korzyści z internacjonalizacji waluty krajowej, takich jak: zyski z renty senioralnej, obniżka rentowności obligacji rządowych i spadek kosztu pozyskania kapitału, możliwość zaciągania długu za granicą we własnej walucie oraz wzrost prestiżu, siły politycznej i pozycji kraju w gospodarce światowej.

W artykule wskazano, że przyjęta przez Chiny strategia internacjonalizacji renminbi obejmuje przede wszystkim pięć obszarów: zwiększanie elastyczności systemu kursu walutowego, liberalizację rozliczeń handlowych w renminbi, liberalizację przepływów kapitału (w zakresie inwestycji bezpośrednich i portfelowych), wspieranie rozwoju centrów offshore dla renminbi oraz zawieranie umów o swapach walutowych. Wskutek realizowanej przez władze Chin strategii internacjonalizacji renminbi nastąpił szybki wzrost międzynarodowego wykorzystania chińskiej waluty (wzrost udziału renminbi w rozliczaniu handlu światowego, $\mathrm{w}$ światowych płatnościach, $\mathrm{w}$ średnim dziennym obrocie na światowym rynku walutowym oraz w światowych rezerwach walutowych). 


\section{Źródła finansowania}

Badanie sfinansowano z dotacji statutowej Kolegium Gospodarki Światowej Szkoły Głównej Handlowej w Warszawie.

\section{Bibliografia}

BIS, 2013, Triennial Central Bank Survey 2013, Bank for International Settlements, Basel.

BIS, 2016, Triennial Central Bank Survey 2016, Bank for International Settlements, Basel.

Chinn M., Frankel J., 2005, Will the Euro Eventually Surpass the Dollar as Leading International Reserve Currency?, Working Paper no. 11510, The National Bureau of Economic Research, Cambridge.

COFER, 2017, Currency Composition of Official Foreign Exchange Reserves, International Monetary Fund, Washington.

Cohen B., 2012, The Benefits and Costs of an International Currency. Getting the Calculus Right, Open Economies Review, vol. 23, issue 1.

ECB, 2014, The International Role of the Euro, European Central Bank, July.

Eichengreen B., 2011, Exorbitant Privilege. The Rise and Fall of the Dollar, Oxford University Press, Oxford.

Gao H., Yu Y., 2011, Internationalisation of the Renminbi, [w:] Currency Internationalisation. Lessons from the Global Financial Crisis and Prospects for the Future in Asia and the Pacific, Bank for International Settlements, Basel.

Genberg H., 2009, Currency Internationalisation. Analytical and Policy Issues, Working Paper no. 31/2009, Hong Kong Institute for Monetary Research, Hong Kong.

Goldstein M., Lardy N., 2008, Debating China's Exchange Rate Policy, Peterson Institute for International Economics, Washington.

Hong Kong. The Premier Offshore Renminbi Business Centre, 2015, Hong Kong Monetary Authority.

Huang Y., Wang D., Fan G., 2014, Paths to a Reserve Currency. Internationalization of the Renminbi and Its Implications, Asian Development Bank Institute, Tokyo.

IMF, 2015a, Press Release No. 15/540, International Monetary Fund, Washington 01.12.2015.

IMF, 2015b, Survey on the Holdings of Currencies In Official Foreign Currency Assets, International Monetary Fund, Washington.

IMF, 2016a, RMB Internationalization Report 2016, International Monetary Fund, Washington.

IMF, 2016b, Press Release No. 16/90, International Monetary Fund, Washington 04.03.2016.

Ito I., 2011, The Internationalization of the RMB. Opportunities and Pitfalls, The Council on Foreign Relations, New York.

Jackson W., Rossi V., 2011, Hong Kong's Role In Building the Offshore Renminbi Market, International Economics Programme Paper no. IE PP 2011/01, Chatham House, London.

Jiabao W., 2011, Report on the Work of the Government, Fourth Session of Eleventh National People's Congress, Beijing, 5.03.2011.

Kenen P., 2011, Currency Internationalisation. An Overview, [w:] Currency Internationalisation. Lessons from the Global Financial Crisis and Prospects for the Future in Asia and the Pacific, Bank for International Settlements, Basel.

Papaioannou E., Portes R., 2008, Costs and Benefits of Running an International Currency, Economic Paper no. 348, European Commission, Brussels. 
Prasad E., Ye L., 2012, The Renminbi's Role in the Global Monetary System, Discussion Paper no. 6032, Forschungsinstitut zur Zukunft der Arbeit, Bonn.

Renminbi Trade Settlement Pilot Scheme, 2009, Hong Kong Monetary Authority Quarterly Bulletin, Hong Kong.

Report to Congress on International Economic and Exchange Rate Policies, 2013, U.S. Department of the Treasury.

Skopiec D., 2016, Znaczenie porozumień swapowych banków centralnych w tworzeniu oficjalnej płynności międzynarodowej, International Business and Global Economy, no. 35/2, Uniwersytet Gdański, Gdańsk.

Subacchi P., 2010, One Currency, Two Systems. China's Renminbi Strategy, Briefing Paper no. IE BP 2010/01, The Royal Institute of International Affairs, London.

Subramanian A., 2011, Eclipse. Living in the Shadow of China's Economic Dominance, Peterson Institute for International Economics, Washington.

SWIFT, 2013, SWIFT RMB Tracker. RMB now 2nd most used currency in trade finance, overtaking the Euro, November.

The World Bank, 2017, World Development Indicators Database.

WTO, 2017, Statistics Database, Trade Profiles.

D.A. Skopiec (®) dskopiec@sgh.waw.pl

Szkoła Główna Handlowa w Warszawie, al. Niepodległości 162, 02-554 Warszawa, Polska 